\title{
Sex symbols ancient and modern: their origins and iconography on the pedigree
}

\author{
G D Schott
}

Sex symbols on pedigrees were illustrated quite differently 150 years ago. What brought about the change?

\begin{abstract}
Nowadays no scientific paper on genetics involving an extensive family history would be complete without depiction of the pedigree, on which squares represent the male members of the family and circles represent the females. But it was not always so, and a century ago ancient and modern symbols vied with each other in the genetic and eugenic literature. ${ }^{1}$ The origin and iconography of these symbols, one pair with a history dating back many centuries, the other pair originating in 1845 , are the subjects of this discussion.
\end{abstract}

\section{Classical origins}

At the beginning of the 20th century the male and female symbols on pedigrees (fig 1) were often variations of the ancient symbols classically associated with Mars and Venus. The history of their introduction into medicine was lengthy and circuitous, beginning with astronomy and astrology-and leading via alchemy, chemistry, and pharmacy to botany-before reaching human biology and genetics. ${ }^{2}$

For the ancients, movements of the heavenly bodies seemed to influence the seasons and thus the cycles of growth of plants and of breeding of animals. These heavenly bodies had become associated with the names of gods, a concept the ancient Greeks acquired from the Babylonians. Later, religious rites that revolved around the seasons and were practised by many crafts (but particularly those involving metalwork) formed the links between the gods, astronomical signs, and metals. Metaphorically, in comparison with the sun and the purest metal gold, iron was baser, harder, and associated with Mars and the masculine; copper, which was also base, was softer and associated with Phosphoros or Venus and the feminine. ${ }^{2}$

What of the graphic symbols themselves? The most established view is that they are derived from contractions in Greek script of the Greek names of these planets, namely Thouros (Mars) and Phosphoros (Venus). These derivations have been traced by Renkama, who illustrated how Greek letters can be transformed into the graphic male and female symbols still recognised today (fig 2). ${ }^{3}$

The 18th century plant biologist Linnaeus was instrumental in the widespread introduction of the classical symbols of alchemy, chemistry, and pharmacy into botany. He introduced these symbols as a kind of shorthand "for reasons of economy in recording" and "in order to save space," having himself copied the symbols representing male and female flowers from the 17 th century Pharmacopoeia Leovardensis. ${ }^{2}$ It was then but a short step for the symbols to be incorporated into zoology, human biology, and genetics. Although they were used extensively in pedigrees a century ago (see fig 1) and recommended by leading British geneticists of the time such as Galton and Pearson, these classical symbols gradually yielded to today's square and circle, which also have a curious history.

\section{Squares and circles}

The first to illustrate a pedigree with squares and circles seems to have been Pliny Earle, physician to the Bloomingdale Asylum for the Insane in New York. In 1845, when describing the inheritance of colour blindness in members of his own family, Earle wrote: "For the purpose of clearly illustrating the prevalence of this physiological peculiarity in the family, I have prepared the subjoined genealogical chart. Males are represented by squares and females by circles. For those [affected subjects] who cannot distinguish colours the squares and circles are wholly black" (fig 3 ). ${ }^{4}$

Although Earle does not report why he used these symbols, a contemporary account refers to Edward Nettleship, fellow of the Royal Society and consultant ophthalmic surgeon to the Royal London Ophthalmic and St Thomas's Hospitals, who provides the probable

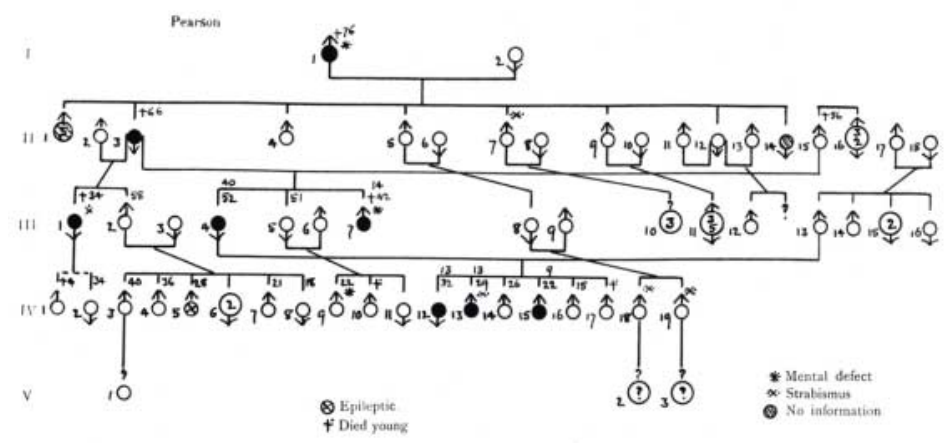

Fig 1 One version of the classical male and female symbols on a pedigree. Filled symbols denote clinically affected individuals with facio-scapulo-humeral muscular dystrophy ${ }^{10}$

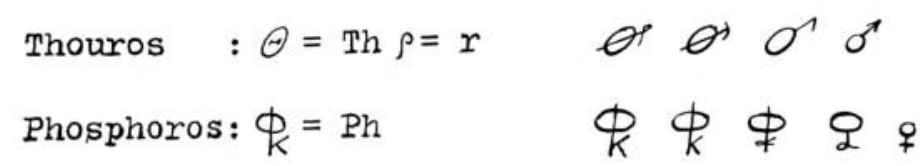

Fig 2 Derivation of the classical male and female pedigree symbols, Thouros and Phosphoros, from Greek letters ${ }^{3}$

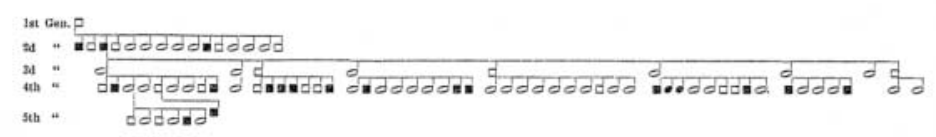

Fig 3 Contemporary male and female symbols were first used in this pedigree of colour blindness in $1845^{4}$ 
answer. Nettleship, who did not approve of the use of squares and circles, explained that at the time Earle was "unable to get any printer's symbols capable of use for his purpose except those employed in printing music." Indeed, careful inspection of figure 3 shows the circles have the slightly elliptical shape of musical notes, in keeping with Nettleship's observation that the affected and unaffected female symbols resembled respectively crotchets and oval semibreves (or, perhaps more convincingly, minims).

Nettleship conceded that "this fragment of history does not affect the merits of the question at issue in its practical aspect, and it could not be quoted as in any way weakening the position of those who favour the retention of the classical biological symbols." ${ }^{\text {"5 }}$ His comment, epitomising the difference in opinion on the merits of using the classical symbols versus the square and circle, mainly reflected the different national preferences. Thus many British geneticists, a number of whom were also eugenicists, favoured the classical symbols, whereas the Americans favoured the modern ones-on the valid grounds that the modern symbols were easier to read and took up less space.

The pedigree in figure 4 provides a striking example of the use of the square and circle. It not only shows the early use of the American symbols in England, but also has deliberately been manipulated for a variety of political and social purposes by the eugenicists of the day. ${ }^{6}$ Also, this pedigree illustrates a remarkable dynasty. Applying the convention whereby roman numerals ordered vertically downwards delineate successive generations, and arabic numerals sequenced rightwards delineate individuals, famous members of this family can be pinpointed and include the pottery designer and manufacturer Josiah Wedgwood (I-1); the eminent physician Erasmus Darwin (I-4); the evolutionary biologist and naturalist Charles Darwin (III-3); and the eugenicist and pioneer of heredity Francis Galton (III-9)

\section{An established convention}

At the beginning of the 20th century, rather quaint depictions of pedigrees and symbols were occasionally to be found, and texts sometimes showed examples using both styles of pedigree. ${ }^{1}$ Nevertheless, although the classical symbols are rarely still to be seen, ${ }^{7}$ the square and circle came to dominate illustrations of the

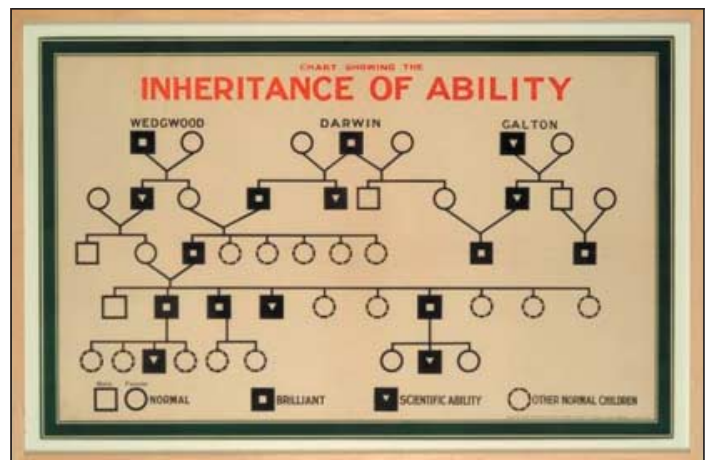

Fig 4 The clarity and simplicity of contemporary symbols, as illustrated by the Wedgwood-Darwin-Galton pedigree. Published by the Eugenics Education Society, 1909. Reproduced with permission of Museum of London

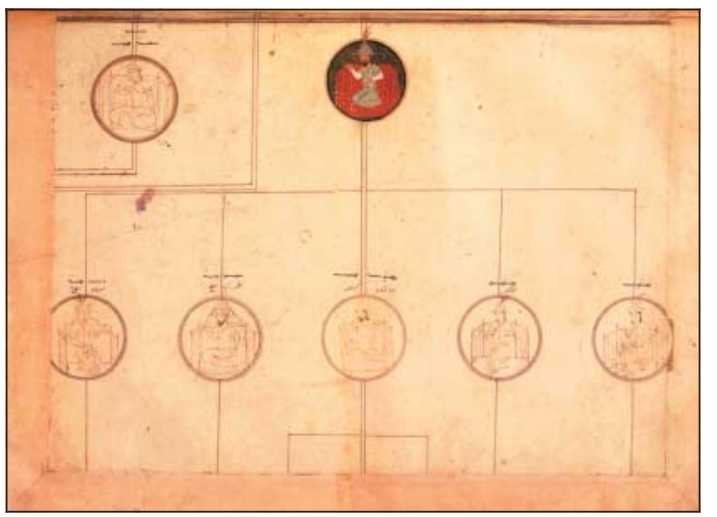

Fig 5 Husain b. Ali Shah. 15th century Turko-Mongol genealogy, probably made for Khalil Sultan, showing linked circles for men, symbolic of heaven. H2152; reproduced with permission of the Topkapi Sarayi Müzesi, Istanbul

pedigree. This was not only for reasons of simplicity and space, but also for other reasons, such as the greater ease of representing affected, unaffected, and carrier individuals.

If square and circle are now taken for granted, the origin of even such an established convention may be open to debate. Returning to classical times, but now to genealogies of the Turko-Mongol rulers of 500 years ago, many pedigrees include the opposite convention-so that circles denote males and squares denote females (fig 5). At least in some illustrations "round médaillons, symbolic of heaven are reserved to men whose dominant elements were considered fiery, hence heavenly. Women, on the other hand, are shown within square frames, the earth, a feminine element, being viewed as quadrangular." ${ }^{8}$ As a generalisation this is too sweeping, however, and in some Mongol genealogies males are shown in square frames-similar to today's convention (JE Woods, personal communication, 2005).

Inconsistency in pedigree design and the use of symbols continues, leading to calls for standardisation. ${ }^{9}$ But at least consensus and widespread acceptance have now been achieved for using squares to represent males and circles for females on pedigrees illustrated today.

I am indebted to John E Woods, professor of history, University of Chicago, for his advice on Turko-Mongol genealogies. Competing interests: None declared.

1 Resta RG. The crane's foot: the rise of the pedigree in human genetics. J Genetic Couns 1993;2:235-60.

Stearn WT. The origin of the male and female symbols of biology. Taxon 1962;11:109-13.

3 Renkema HW. Oorspong, beteekenis en toepassing van de in de botanie gebuikelijke teekens ter aanduiding van het geslacht en den levensduur. In: Jeswiet J, ed. Gedendenkboek J Valckenier Suringar. Wageningen: Nederlandsche Dendrologische Vereeniging, 1942:96-108.

Earle P. On the inability to distinguish colours. Am J Med Sci 1845 ; NS9:346-54.

Discussion. Eugenics Reu 1913-4;5:66-7.

Discussion. Eugenics Rev 1913-4;5:66-7.
Resta RG. Whispered hints. Am J Med Genet 1995;59:131-3.

Cavalli-Sforza LL, Bodmer WF. The genetics of human populations. San Francisco: Freeman, 1971:466.

8 Esin E. Hanlar ulaki (the Succession of Kings). On the illustrated genealogy, with Uygur inscriptions, of Mongol and Temürid dynasties at the Topkapi library. In: Heissig W, Sagaster K, eds. Gedanke und Wirkung: Festschrift zum 90. Geburtstag von Nikolaus Poppe. Wiesbaden: Harrassowitz 1989:113-27.

9 Bennett RL, Steinhaus KA, Uhrich SB, O'Sullivan CK, Resta RG, Lochner-Doyle D, et al. Recommendations for standardized human pedigree nomenclature. Am J Hum Genet 1995;56:745-52.

10 Pearson K. Two new pedigrees of muscular dystrophy. Ann Eugenics 1933;5:179-91. 